\title{
Peningkatan Mutu Produk Jamu Home Industry pada Kelompok Jamu Gendong Desa Karangrejo Kabupaten Magetan di Masa Pandemi Covid-19
}

\author{
Cicilia Novi Primiani ${ }^{*}$, Pujiati, Mohammad Arfi Setiawan \\ Pendidikan Biologi, Fakultas Keguruan dan Ilmu Pendidikan, Universitas PGRI Madiun \\ Teknik Kimia, Fakultas Teknik, Universitas PGRI Madiun \\ *Corresponding Author. Email: primiani@unipma.co.id
}

\begin{abstract}
The purpose of this community service activity is to improve the quality of jamu gendong products at the home industry of jamu gendong in Karangrejo village, Magetan Regency. The method of service is carried out by training, including procedures for pre-survey activities, surveys, socialization, training, and evaluation. The target of the service activity is the women of the jamu gendong group. The evaluation results showed an increase in participant understanding of $56 \%$ about the technique of selecting rhizomes for herbal medicine, an increase in participant understanding of $44 \%$ about equipment selection techniques for herbal medicine, an increase in participant understanding of $72 \%$ about the hygienic process of making herbal medicine, an increase in participant understanding of $66 \%$ about the hygienic packaging process of herbal medicine. The results of monitoring and evaluation showed that $100 \%$ of participants were satisfied in participating in the activities, $100 \%$ of participants took an active role in participating in the training, $100 \%$ of participants were enthusiastic in participating in the activities.
\end{abstract}

\begin{abstract}
Abstrak: Tujuan kegiatan pengbdian masyarakat ini adalah untuk meningkatkan mutu produk jamu gendong pada home industry jamu gendong di desa Karangrejo Kabupaten Magetan. Metode pengabdian dilakukan dengan pelatihan, meliputi prosedur kegiatan pra survey, survey, sosialisasi, pelatihan, dan evaluasi. Sasaran kegiatan pengabdian adalah ibu-ibu kelompok jamu gendong. Hasil kegiatan menunjukkan adanya peningkatan pemahaman peserta sebesar 56\% tentang teknik pemilihan rimpang untuk jamu, peningkatan pemahaman peserta sebesar $44 \%$ tentang teknik pemilihan peralatan untuk pembuatan jamu, peningkatan pemahaman peserta sebesar $72 \%$ tentang proses pembuatan jamu yang higienis, peningkatan pemahaman peserta sebesar $66 \%$ tentang proses pengemasan jamu yang higienis. Hasil monitoring dan evaluasi menunjukkan bahwa $100 \%$ peserta puas dalam mengikuti kegiatan, $100 \%$ peserta berperan aktif dalam mengikuti pelatihan, $100 \%$ peserta antusias dalam mengikuti kegiatan.
\end{abstract}

\section{Article History:}

Received: 10-09-2021

Reviewed: 25-09-2021

Accepted: 15-10-2021

Published: 13-11-2021

\section{Key Words: \\ Training, \\ Home Industry, \\ Jamu, Quality.}

\section{Sejarah Artikel:}

Diterima: 10-09-2021

Direview: 25-09-2021

Disetujui: 15-10-2021

Diterbitkan: 13-11-2021

\author{
Kata Kunci: \\ Pelatihan, \\ Home Industry, Jamu, \\ Mutu.
}

How to Cite: Primiani, C., Pujiati, P., \& Setiawan, M. (2021). Peningkatan Mutu Produk Jamu Home Industry pada Kelompok Jamu Gendong Desa Karangrejo Kabupaten Magetan di Masa Pandemi Covid-19. Jurnal Pengabdian UNDIKMA, 2(2), 142-149. doi:https://doi.org/10.33394/jpu.v2i2.4128

https://doi.org/10.33394/jpu.v2i2.4128

This is an open-access article under the CC-BY-SA License.

\section{Pendahuluan}

Jamu merupakan warisan nenek moyang bangsa Indonesia, yang telah menjadi bagian budaya dan kekayaan alam Indonesia. Upaya meningkatkan kesehatan sampai saat ini masih banyak menggunakan jamu, yang dikonsumsi secara mandiri oleh masyarakat untuk mengobati maupun menjaga kesehatan (Handayani, \& Kristiana, 2011; Kusumo dkk., 2020). Masyarakat mempunyai kebiasaan mengkonsumsi jamu sejak jaman dulu sekitar sebanyak 70\%-80\% masyarakat memanfaatkan jamu sebagai obat tradisional (Prastiwi, 2018). 
Masyarakat terbiasa membuat ramuan dari berbagai macam tumbuhan yang dikonsumsi secara turun temurun (Prasanti, 2018; Harefa, 2020). Jamu digunakan untuk kecantikan, kebugaran, dan menjaga kesehatan tubuh. Jamu dapat juga digunakan untuk menjaga daya tahan tubuh (Kusumo dkk., 2020; Pertiwi dkk., 2020; Sutana, \& Dwipayana, 2020; Sugiarto dkk., 2021).

Masyarakat mengonsumsi jamu dengan cara membuat ramuan secara mandiri maupun membeli dari penjual jamu. Penjual jamu seringkali disebut sebagai penjual jamu gendong, yang membuat kemasan jamu secara tradisonal (Safitri dkk., 2017; Rosidah dkk., 2018; Muliasari dkk., 2019). Kemasan jamu gendong biasanya menggunakan botol, kemudian dipasarkan dengan cara berkeliling. Salah satu pusat produksi jamu gendong yaitu Desa Karangrejo Kabupaten Magetan.

Jamu produksi dari desa Karangrejo sudah terkenal sampai ke luar kota dan provinsi (Ardiana \& Cendriono, 2017). Desa Karangrejo terletak di selatan desa Belotan dan dikelilingi oleh Sungai Gandong. Banyak ibu di desa Karangrejo yang berprofesi sebagai penjual jamu gendong yang dijajakan keliling dari desa ke desa. Penjaja jamu gendong dari Desa Karangrejo Kabupaten Magetan adalah ibu-ibu yang tergabung dalam kelompok jamu gendong berusia 40-60 tahun, berjumlah sekitar 60 orang.

Proses pembuatan jamu biasanya dilakukan oleh ibu-ibu penjual jamu gendong, dilakukan secara mandiri mulai dari mengadakan bahan baku, meracik dan memasarkan jamu. Ibu-ibu yang tergabung dalam kelompok jamu gendong secara mandiri melakukan pekerjaannya mulai dari memilih rimpang, merebus, menumbuk/menghaluskan, mengemas, dan memasarkannya. Ibu-ibu kelompok jamu gendong Desa Karangrejo Kabupaten Magetan merupakan pengusaha sekaligus pekerja dan penjual jamu gendong. Semua proses produksi dan pemasaran jamu gendong dilakukan secara mandiri.

Berdasarkan hasil observasi, permintaan jamu gendong pada masa pandemi Covid-19 mengalami peningkatan. Banyak permintaan jamu oleh masyarakat, dengan alasan untuk meningkatkan daya tahan tubuh. Jamu gendong yang diproduksi merupakan jamu olahan segar, dalam bentuk cair yang dikemas dalam botol. Jenis jamu gendong yang diproduksi berupa jamu kunyit asam, beras kencur, dan jamu pahitan/cabe puyang. Meskipun demikian, ada beberapa permasalahan yang dihadapi para penjual jamu gendong Desa Karangrejo Kabupaten Magetan. Permasalahan yang dihadapi adalah, keluhan konsumen karena penurunan kualitas rasa jamu dan tidak bertahan lama. Temuan yang ada di home industry jamu gendong Desa Karangrejo Kabupaten Magetan adalah produktivitas yang tetap dan monoton, dan masih belum sebanding dengan permintaan pasar. Para penjual jamu gendong setiap hari memproduksi jamu gendong dalam skala kecil, karena para penjual jamu berpedoman bahwa penjualan cukup hanya dilakukan dalam sehari. Penjualan dilakukan mulai pukul 06.00 dengan menjajakan dagangannya hingga pukul 11.00. Singkatnya waktu penjualan jamu gendong, karena masa simpan jamu bentuk cair sangat singkat, tidak dapat bertahan dalam waktu lama, dengan cepat basi dan berubah rasa.

Tujuan pengabdian ini adalah meningkatkan mutu produk jamu gendong dengan memberikan pemahaman proses pembuatan jamu secara higienis kepada para penjual jamu gendong di home industri jamu gendong Desa Karangrejo Kabupaten Magetan melalui pelatihan. Adanya pengabdian ini, diharapkan para penjual jamu gendong di home industry jamu gendong dapat memproduksi jamu dengan menerapkan proses pembuatan jamu sesuai dengan standar kesehatan. Hal ini dapat meningkatkan penyediaan jamu sebagai minuman sehat dan berkhasiat di masa pandemi Covid-19. 


\section{Metode Pengabdian}

Kegiatan pengabdian ini dilaksanakan di Desa Karangrejo Kabupaten Magetan pada home industry jamu gendong, mulai bulan Maret s/d Juni 2021. Metode pelaksanaan kegiatan ini yakni pelatihan, dengan prosedur pra survey, survey, sosialisasi, pelatihan, dan evaluasi. Adapun penjelasan prosedurnya adalah sebagai berikut:

\section{1) Pra Survey}

Tahap pra survey dilakukan beberapa kali dengan teknik wawancara kepada kepala desa, dan perangkat desa lain serta kelompok jamu gendong. Tujuan pra survey untuk menggali informasi terkait pengetahuan, pemahaman dan konsep mengenai jamu gendong yang selama ini telah dilakukan oleh ibu-ibu kelompok jamu gendong serta kendala-kendala yang dihadapi. Hasil diskusi yang diperoleh akan diterjemahkan dalam bentuk kuisioner yang dipergunakan mendukung kegiatan survey.

\section{2) Survey}

Tahap survey dilakukan dengan teknik wawancara dan observasi. Wawancara dan observasi dilakukan kepada kelompok jamu gendong. Teknik wawancara menggunakan beberapa indikator. Adapun beberapa indikator pertanyaan meliputi: 1) Bagaimana teknik pembuatan jamu gendong yang selama ini dilakukan? 2) Bagaimanakah cara memperoleh rimpang untuk pembuatan jamu? 3) Berapa banyak produksi jamu setiap harinya? 4) Bagaimanakah proses menghaluskan rimpang yang selama ini dilakukan? 5) Bagaimanakah teknik perebusan rimpang yang selama ini dilakukan? 6) Bagaimanakah pemasaran jamu gendong selama ini dilakukan?

\section{3) Sosialisasi/Penyuluhan}

Tahap sosialisasi/penyuluhan dilakukan menggunakan teknik ceramah dan diskusi informasi, dengan peserta kelompok jamu gendong. Tahap sosialisasi/penyuluhan dilakukan dengan memberikan penjelasan mengenai teknik pembuatan jamu gendong yang higienis dan berkualitas.

\section{4) Pelatihan}

Tahap pelatihan yang dilakukan dengan praktek pembuatan jamu yang berkualitas, mulai dari teknik pemilihan bahan baku, teknik pemilihan peralatan, teknik perebusan dan penghalusan/pemerasan. Peserta melakukan praktek secara langsung dengan pendampingan.

\section{5) Evaluasi}

Kegiatan evalusi dilakukan setelah keseluruhan metode dilakukan, hal ini untuk mengetahui tingkat keberhasilan program. Evaluasi dilakukan dengan membandingkan indikator ketercapaian program sebelum dan setelah dilakukan pelatihan peningkatan mutu produk jamu gendong. Instrumen evaluasi menggunakan angket dan dianalisis secara deskriptif.

\section{Hasil Pengabdian dan Pembahasan}

Pelaksanaan kegiatan pengabdian yang dilakukan dengan tujuan untuk meningkatkan mutu produk jamu pada kelompok jamu gendong Desa Karangrejo Kabupaten Magetan. Hasil yang diperoleh dari masing-masing kegiatan adalah sebagai berikut.

\section{1) Hasil Kegiatan Pengabdian pada Tahap Pra Survey}

Tahap pra survey dilakukan dengan teknik wawancara dengan kepala desa, dan perangkat desa lain serta kelompok jamu gendong (Gambar 1). Pada saat wawancara kepada kepala desa ada beberapa temuan yang disampaikan, yaitu: 1) Industri jamu gendong Desa Karangrejo Kabupaten Magetan sudah dilakukan puluhan 
tahun, dan produk jamu sudah dikenal luas ke luar desa bahkan ke kabupaten lain. Teknik pembuatan jamu gendong dilakukan secara tradisional (ditumbuk dan direbus), produk jamu cair kemasan botol, 2) Pemasaran jamu gendong dilakukan secara manual, dengan wilayah pemasaran di luar desa dan sebagian dibawa ke luar wilayah Kabupaten Magetan, menggunakan sepeda/sepeda motor, 3) Jumlah produksi jamu gendong dengan kapasitas terbatas, yang diproduksi mulai pukul 06.00 selanjutnya dipasarkan, dan selesai memasarkan sekitar pukul 11.00, 4) Kelebihan produksi jamu gendong terutama pada masa pandemi Covid-19 adalah bertambahnya permintaan pasar dan konsumen menyukai rasa jamu sangat kental, 5) Kelemahan produksi jamu gendong adalah kurang dapatnya memenuhi kebutuhan pasar, karena jamu gendong tidak bertahan lama/tidak awet.
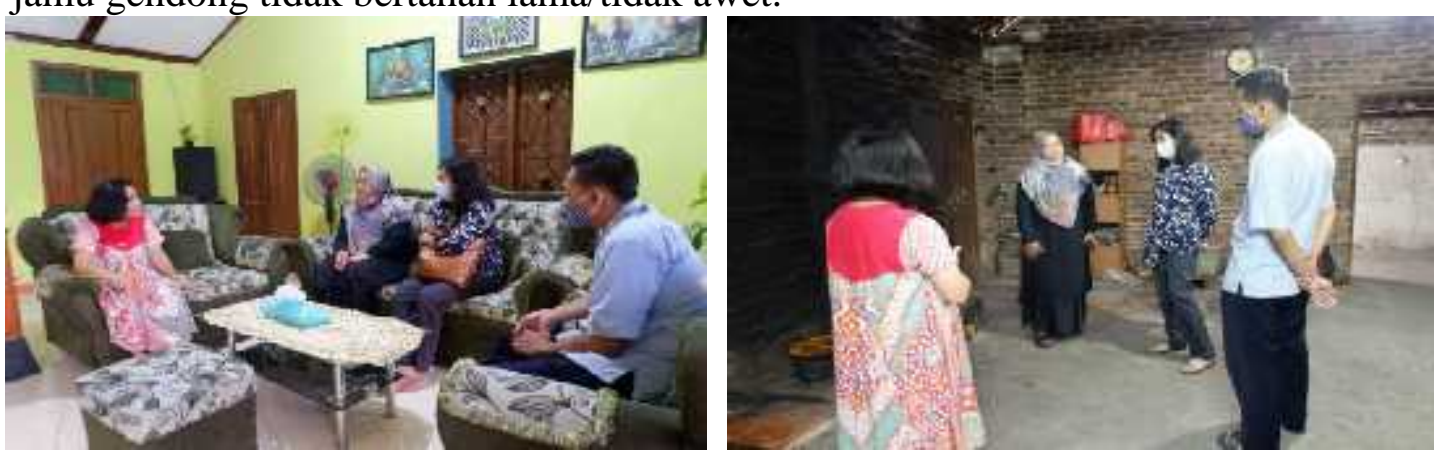

Gambar 1. Kegiatan Observasi dan Wawancara kepada Salah Satu Penjual Jamu Gendong

2) Hasil Kegiatan Pengabdian pada Tahap Survey

Kegiatan survey/observasi dilakukan melalui pemantauan langsung di lokasi Desa Karangrejo Kabupaten Magetan. Observasi dilakukan kepada para penjual jamu gendong, dengan beberapa temuan yaitu: 1) Pembuatan jamu gendong dilakukan dengan teknik tradisional yaitu dengan cara ditumbuk dan proses perebusan dilakukan dalam panci aluminium. Ibu-ibu pembuat jamu gendong tidak mengetahui teknik/proses pembuatan jamu gendong secara higienis, 2) Produk jamu gendong berupa jamu kemasan dalam botol yang tidak bisa bertahan lama, 3) Pengemasan dan pemasaran dilakukan menggunakan menggunakan botol bekas air mineral, 4) Produksi yang dilakukan dalam sehari sekitar 10-15 botol, 5) Pemasaran dilakukan secara mandiri dengan jangkauan terbatas.

3) Hasil Kegiatan Pengabdian pada Tahap Sosialisasi/Penyuluhan

Kegiatan sosialisasi/penyuluhan dilakukan dengan peserta kelompok jamu gendong. Kegiatan sosialisasi/penyuluhan dilakukan dengan memberi motivasi kepada ibu-ibu yang tergabung dalam kelompok jamu gendong untuk terus memproduksi jamu gendong yang lebih sehat dan inovatif. Teknik sosialisasi/penyuluhan dengan ceramah dan diskusi informasi.

Materi sosialisasi/penyuluhan mengenai teknik pembuatan jamu gendong secara higienis. Peserta diberikan penjelasan mengenai teknik pemilihan rimpang yang baik untuk jamu, teknik pengolahan rimpang dengan perebusan secara higienis, dan teknik sterilisasi botol kemasan secara sederhana. Peserta sangat antusias dalam mengikuti kegiatan penyuluhan. Peserta banyak mengajukan berbagai pertanyaan dan diskusi. Jumlah peserta yang hadir adalah 10 orang sesuai dengan rencana sebagai perwakilan kelompok jamu gendong. Kegiatan ceramah dan diskusi dapat berjalan dengan baik. 
Materi penyuluhan disampaikan secara terstruktur, dengan media LCD sehingga peserta dapat memahami materi dengan baik. Materi juga diberikan dalam bentuk leaflet, sehingga mudah dipahami oleh peserta. Materi penyuluhan bertujuan memberikan pemahaman kepada kelompok jamu gendong bahwa jamu merupakan herbal medicine yang perlu pengolahan secara baik dan benar, sehingga aman, bermutu dan bermanfaat bagi kesehatan. Mutu/kualitas jamu supaya layak dikonsumsi dengan persyaratan tidak tercemar baik secara fisik, kimia, dan mikrobiologi. Jamu yang berkualitas juga memiliki ciri tidak rusak, artinya jamu yang diolah tidak mengalami perubahan warna, rasa dan bau.

Kegiatan sosialisasi/penyuluhan juga dihadiri oleh kepala desa, yang memberikan motivasi kepada peserta untuk meningkatkan produktivitas jamu gendong yang berkualitas. Kepala desa sangat memberikan dukungan dan perhatian pada kegiatan ini, dengan memberikan ide-ide inovatif untuk pengembangan jamu gendong, serta menyediakan lahan untuk penanaman bibit rimpang.
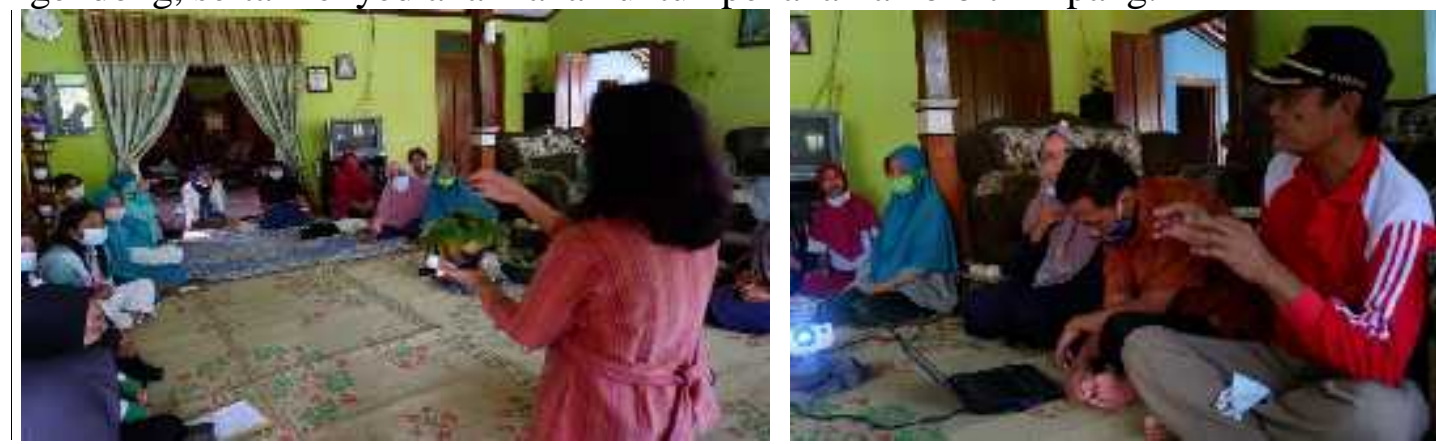

Gambar 2. Kegiatan Sosialisasi/Penyuluhan Pembuatan Jamu Gendong yang Higienis. Kepala Desa Karangrejo Memberikan Perhatian kepada Kelompok Jamu Gendong

\section{Hasil Kegiatan Pengabdian pada Tahap Pelatihan}

Tahap kegiatan pelatihan dilakukan dengan praktek secara langsung pembuatan jamu yang higienis dan berkualitas. Pelatihan dimulai dari a) Teknik pemilihan bahan baku/pemilihan rimpang yang baik, b) Teknik pemilihan peralatan, c) Teknik menghaluskan rimpang dengan menumbuk/memblender, d) Teknik perebusan, e) Teknik sterilisasi botol secara sederhana, dan f) Teknik pengemasan ke dalam botol. Peserta pelatihan mengikuti serangkaian kegiatan dengan antusias dan penuh perhatian

Pelatihan dilakukan dengan praktek secara langsung, dimulai dengan pelatihan materi pertama pemilihan rimpang. Teknik pemilihan rimpang untuk jamu adalah rimpang yang telah tua, tidak busuk, tidak bertunas, kulit rimpang tampak halus, tidak kisut, mengkilat, penampang melintang berwarna cerah, dan bebas hama. Rimpang yang telah dipilih dengan baik, selanjutnya dikupas dan dicuci bersih di bawah air mengalir.

Pelatihan dilanjutkan pada materi kedua yaitu teknik pemilihan peralatan yang digunakan untuk merebus dan menghaluskan rimpang. Peralatan yang digunakan adalah peralatan yang aman bagi kesehatan (food grade). Panci yang digunakan untuk proses perebusan adalah panci berbahan enamel, tanah liat, atau stainless steel, bukan panci aluminium. Peralatan lain yang digunakan berupa botol yang terbuat dari kaca, bukan menggunakan botol bekas air mineral. 
Pelatihan materi ketiga adalah teknik menghaluskan rimpang dengan menumbuk/memblender. Teknik menumbuk rimpang dapat dilakukan dengan lumpang yang bersih, khusus untuk menumbuk rimpang dan tidak bercampur dengan lumpang lain. Teknik menghaluskan rimpang juga dapat dilakukan dengan menggunakan blender. Blender yang digunakan adalah blender bersih dan khusus digunakan untuk memblender rimpang, tidak bercampur dengan bahan lain.

Pelatihan materi keempat adalah teknik pengemasan ke dalam botol. Botol yang digunakan untuk pengemasan jamu adalah botol yang terbuat dari kaca, bukan botol plastik. Botol-botol kemasan yang digunakan adalah botol kaca higienis, oleh karena itu botol kaca perlu dilakukan sterilisasi. Kegiatan pelatihan sterilisasi botol kaca secara sederhana, dilakukan oleh kelompok jamu gendong, dengan memanaskan pada suhu $100{ }^{\circ} \mathrm{C}$ botol kaca dalam panci.

Pelatihan materi kelima adalah teknik pengemasan ke dalam botol. Pengemasan jamu ke dalam botol merupakan rangkaian proses pembuatan jamu gendong, sehingga jamu siap dipasarkan dalam kondisi segar. Pengemasan perlu dilakukan untuk memberikan identitas terhadap jamu dalam botol, serta identitas produksi.
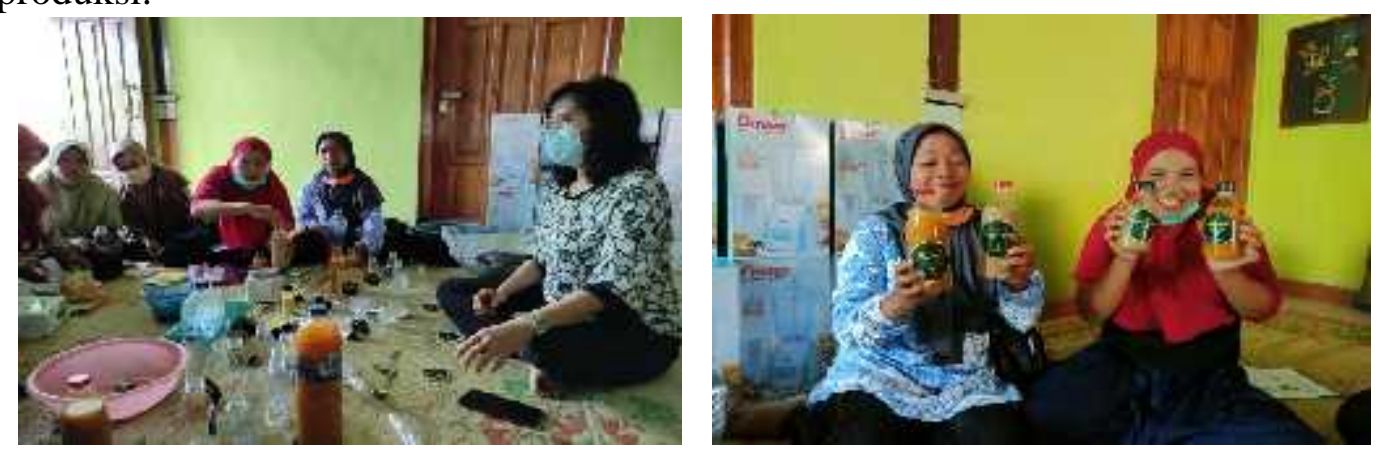

Gambar 3. Kegiatan Pelatihan Pembuatan Jamu Gendong yang Higienis dan Pengemasan Produk

\section{Evaluasi}

Kegiatan evaluasi merupakan rangkaian proses kegiatan setelah kegiatan pelatihan dilaksanakan. Evaluasi dilakukan untuk mengetahui tingkat keberhasilan proses kegiatan peningkatan mutu produk jamu gendong Desa Karangrejo Kabupaten Magetan. Adapun hasil evaluasi keterlaksanaan program seperti terdapat pada Tabel berikut.

Tabel 1. Analisis Hasil Angket dan Kategori

\begin{tabular}{lcc}
\hline \multicolumn{1}{c}{ Kegiatan } & $\begin{array}{c}\text { Sebelum } \\
\text { kegiatan } \\
(\mathbf{\%})\end{array}$ & $\begin{array}{c}\text { Setelah } \\
\text { kegiatan } \\
(\mathbf{\%})\end{array}$ \\
\hline $\begin{array}{l}\text { Peran aktif peserta dalam pelatihan dan kehadiaran } \\
\text { Ketertarikan peserta dalam mengikuti kegiatan }\end{array}$ & 0 & 100 \\
$\begin{array}{l}\text { Pemahaman peserta dalam teknik pemilihan rimpang } \\
\text { untuk jamu }\end{array}$ & 40 & 100 \\
$\begin{array}{l}\text { Pemahaman peserta dalam teknik pemilihan peralatan } \\
\text { untuk pembuatan jamu }\end{array}$ & 56 & 100 \\
$\begin{array}{l}\text { Pemahaman peserta dalam proses pembuatan jamu yang } \\
\text { higian }\end{array}$ & 25 & 97
\end{tabular}




\begin{tabular}{lcc}
$\begin{array}{l}\text { Pemahaman peserta dalam proses pengemasan jamu } \\
\text { yang higienis }\end{array}$ & 30 & 96 \\
Kepuasan peserta dalam mengikuti kegiatan & 0 & 100 \\
\hline
\end{tabular}

Keterlibatan peserta dalam kegiatan pelatihan mengalami peningkatan $100 \%$, peserta sangat antusias mengikuti pelatihan, karena belum pernah ada pelatihan proses pembuatan jamu dalam upaya peningkatan produksi. Ibu-ibu yang tergabung dalam kelompok jamu gendong menjadi paham teknik pemilihan rimpang untuk jamu, mengalami peningkatan $56 \%$. Peserta pelatihan mengalami peningkatan $44 \%$ terkait pemilihan peralatan yang higienis dalam pembuatan jamu. Peningkatan pemahaman peserta dalam pelatihan pengemasan jamu secara higienis meningkat $66 \%$. Keterlaksanaan kegiatan pelatihan dipahami peserta meningkat $72 \%$. Menurut Agustina dkk. (2019) peningkatan keterlaksanaan program dapat meningkatkan mutu produk sehingga dapat meningkatkan daya saing.

Berdasarkan hasil angket peserta berkomitmen untuk melakukan proses pembuatan jamu sesuai dengan mekanisme standar kesehatan yang ditetapkan. Berdasarkan hasil wawancara peserta, perlu dilakukan peningkatan kualitas jamu gendong. Produksi jamu gendong Desa Karangrejo Kabupaten Magetan merupakan produk jamu dengan kualitas baik sehingga dapat dikembangkan sebagai salah satu desa berbasis herbal medicine

Produk jamu gendong Desa Karangrejo Kabupaten Magetan sangat potensi untuk dapat dikembangkan. Pengembangan produk jamu gendong di Desa Karangrejo merupakan program pengembangan keberlanjutan. Keberlanjutan program kegiatan pengabdian Desa Karangrejo Kabupaten Magetan sebagai pusat produksi jamu gendong dapat dikembangkan menjadi desa wisata edukasi berbasis kearifan lokal. Pengembangan kelompok jamu gendong menjadi sarana pengembangan sebagai desa wisata.

\section{Kesimpulan}

Kesimpulan dari kegiatan pengabdian ini yakni telah terjadi peningkatan sebesar $56 \%$ pemahaman peserta tentang teknik pemilihan rimpang untuk jamu. Peningkatan sebesar $44 \%$ pemahaman peserta tentang teknik pemilihan peralatan yang tepat untuk pembuatan jamu. Peningkatan sebesar $72 \%$ pemahaman peserta tentang proses pembuatan jamu yang higienis. Peningkatan sebesar 66\% pemahaman peserta tentang proses pengemasan jamu yang higienis. Hasil monitoring dan evaluasi menunjukkan bahwa $100 \%$ peserta puas dalam mengikuti kegiatan. Peserta berperan aktif dalam mengikuti pelatihan sebesar $100 \%$ peserta antusias dalam mengikuti kegiatan.

\section{Saran}

Adapaun saran yang dapat disampaikan berdasarkan hasil kegiatan ini adalah adanya dukungan dan peran serta pemerintah daerah sangat diperlukan dalam upaya pengembangan berkelanjutan kelompok jamu gendong Desa Karangrejo Kabupaten Magetan. Kegiatan pengabdian dapat dikembangkan dengan memberikan inovasi produk jamu gendong, sehingga menjadi produk jamu gendong yang dapat dikenal luas di pasaran. Inovasi yang dikembangkan tetap berdasar konsep jamu sebagai produk herbal medicine yang dapat mengembangan Desa Karangrejo Kabupaten Magetan sebagai desa wisata jamu. 


\section{Daftar Pustaka}

Agustina, Y., Pratikto, H., Churiyah, M., \& Dharma, B. A. (2019). Pentingnya penyuluhan sertifikasi jaminan produk halal untuk usaha kecil menengah (UKM). Jurnal Graha Pengabdian, 1(2), 139-150.

Ardiana, T. E., \& Cendriono, N. (2017). Peningkatan Usaha Jamu Untuk Menunjang Ekonomi Keluarga Pada Penerima Bantuan Program Jalin Matra Di Desa Karangrejo Kecamatan Kawedanan Kabupaten Magetan. In Prosiding Seminar Nasional Hasil Pengabdian kepada Masyarakat LPPM Universitas PGRI Madiun (pp. 110-114).

Handayani, L., \& Kristiana, L. (2011). Pemanfaatan jamu untuk gangguan kesehatan reproduksi perempuan, analisis lanjut data riset kesehatan dasar tahun 2010. Buletin Penelitian Sistem Kesehatan, 14(3), 21284.

Harefa, D. (2020). Pemanfaatan Hasil Tanaman Sebagai Tanaman Obat Keluarga (TOGA). Madani: Indonesian Journal of Civil Society, 2(2), 28-36.

Kusumo, A. R., Wiyoga, F. Y., Perdana, H. P., Khairunnisa, I., Suhandi, R. I., \& Prastika, S. S. (2020). Jamu Tradisional Indonesia: Tingkatkan Imunitas Tubuh Secara Alami Selama Pandemi. Jurnal Layanan Masyarakat (Journal of Public Services), 4(2), 465471.

Muliasari, H., Ananto, A. D., \& Andayani, Y. (2019). Inovasi Dan Peningkatan Mutu Produk Jamu Pada Perajin Jamu Gendong di Kota Mataram. Prosiding PEPADU, 1(1), 72-77.

Pertiwi, R., Notriawan, D., \& Wibowo, R. H. (2020). Pemanfaatan Tanaman Obat Keluarga (TOGA) Meningkatkan Imunitas Tubuh sebagai Pencegahan COVID-19. Dharma Raflesia: Jurnal Ilmiah Pengembangan dan Penerapan IPTEKS, 18(2), 110-118.

Prasanti, D. (2018). Peran Obat Tradisional Dalam Komunikasi Terapeutik Keluarga Di Era Digital. Jurnal Komunikasi Universitas Garut: Hasil Pemikiran dan Penelitian, 3(1), 17-27.

Prastiwi, R. S. (2018). Pengobatan tradisional (jamu) dalam perawatan kesehatan ibu nifas dan menyusui di Kabupaten Tegal. Jurnal Siklus, 7(1), 263-267.

Rosidah, R., Kusumastuti, A., \& Widodo, R. D. (2018). Pemberdayaan perajin jamu tradisional untuk mendukung program desa wisata wonolopo kecamatan mijen kota semarang. Rekayasa: Jurnal Penerapan Teknologi dan Pembelajaran, 16(1), 69-76.

Safitri, W., Harti, A. S., Putriningrum, R., \& Priambodo, G. (2017). Peningkatan Mutu Produk Dan Pemberdayaan Mitra Perajin Jamu Gendong Melalui Program Ibm. In SEMINAR NASIONAL HASIL-HASIL PENGABDIAN 2017.

Sugiarto, S., Soliha, A., Rhamadan, M. A. S. F., Sholeh, A., Aji, A., Aris, A., ... \& Firda, H. (2021). Upaya Peningkatan Imunitas Masyarakat terhadap Pandemi Covid-19 Delta melalui Pembuatan Jamu Instan. Jurnal Pembelajaran Pemberdayaan Masyarakat (JP2M), 2(2), 160-166.

Sutana, I. G., \& Dwipayana, A. P. (2020). Perilaku Konsumsi Jamu Tradisional Di Tengah Pandemi Covid-19. Poniman, \& J. Simarmata, Covid-19: Perspektif Agama Dan Kesehatan, 41-68. 